\title{
Educators' Favoritism: Evidenced based Opinions of Pupil Teachers
}

\author{
Tariq Hussain, Nisar Abid, Noreen Rafique \\ University of the Punjab, Lahore, Pakistan
}

\begin{abstract}
Favoritism occurs in each discipline of life, specifically in educational organizations. This study is designed to explore the pupil teachers' opinions about favoritism, further to identify the dominant factor of teachers' favoritism at Institute of Education and Research (IER), University of the Punjab, Lahore. The participants were the pupil teachers' enrolled in Master Degree Programme of session (2015-2017). 225 pupil teachers were selected by non-proportional stratified random sampling method. Adapted questionnaire was used in this study which was developed by Dr. Ismail Aydogan (2008) in Turkey. Instrument contained of 28 statements which further divided into its four subscales: nature of preference, violation of rules, students' assessment and terms of communication. Descriptive and Inferential statistical techniques were applied to analyze to data. Results exhibited that majority of pupil teachers agreed that educators give favor to female pupil teachers throughout the educational career. The "nature of preference" is the dominant factor of teachers' favoritism at Institute of Education and Research which shows that teachers give performance to socially well-placed, beautifuNhandsome, relative and ideologically closed learners. It was concluded that there was insignificant difference in the opinions of pupil teachers about favouritism with respect to gender and program (morning and self-support). It is recommended that for accountability determination the management need to develop casual contacts with the learners.
\end{abstract}

\section{Introduction}

Students and teachers are considered as change agent, they have unintentional and intentional relationships with each other and also affected the personality of each other. Favoritism contribute to some hurtful and negligent actions toward others. Favoritism may become barriers to work efficiently together. These barriers get up from undesirable attitudes associated to economic and sociocultural background, primary language spoken, current lifestyle, gender, skin color, status, power, intervention orientation, and so on. In educational institutions it is supposed that teachers give preference to certain learners over others at all levels particularly in universities.

Teachers' favoritism may be defined as the performance of giving special action to something or someone; the propensity to favor a person or group for factors "such as characteristic they own, or their private interactions, or merely out of individual favorites" [2]. Favoritism is perceived as biased practices of treating some individuals better than others [10]. Nalder and Schulman thought favoritism is preferring some individual not person deed and job but giving to more or less peripheral aspects i.e. individual liking and disliking. It extinguishes equivalence as it carries certain benefits to individuals who did not receive them, and it also harms for others' moral intentions [5].

Now a days favoritism is a worldwide problem. Roy and Roy define favoritism as the deed of preferring an individual or group over others who have equal rights [9]. Nepotism is stated as "an element of favoritism given to family members for example acquisition of in-laws, nieces, nephews, and others because of the family relations rather than capability" [1].

Researchers have verified that favoritism occur in their countries, particularly in educational institutions [2] [6] [10]. Favoritism occurs when an educator give favor to a particular individual unjustly and illegally, or gives anyone or any cluster of individuals high grades in assignments and tests. In addition, it is favoritism when worthless individuals are reinvigorated and they acquire greater marks than those who do solid effort in their educations.

Favoritism is giving favor to somebody in unlike way not because of capability in educations nevertheless because of particular benefits. If there is a choice for learner is to be encouraged "deprived of worthy it," even dishonestly, if somewhat occurs "behind secure gates" as of more or less particular reasons containing economic status, physically 
charm, restraint and announcement in educational organizations [2]. If there are two learners with equal competence and presentation in classroom and one of them has worthy presentation nevertheless is not nominated by means of associated to further learner who is close to educator and eventually nominated at that time it is entitled favoritism. Favoritism is one of the most significant reasons affecting teaching therefore learner achievement. There are numerous aspects leading to favoritism between educators. These aspects are learner achievement, learner's economic or social position, gender, physical appearance, and understanding between learner and educator or learner's family and educator (friendship or blood relations), and parallelism among ideology (religious or political) of learners or their family and educator.

Educators are occasionally affected by learner accomplishment or failure. Additional indeed, educators can criticize less successful learners supplementary harshly and have a smaller amount of interaction with them, therefore contravention their inspiration to study. However, they can distinguish certain other learners as high achiever and consequently grow a further positive attitude towards them, which eventually helps them in acquisition of better achievement. Additionally, dominant aspect in educators' favoritism is social class in which learners have its place. Learners from a middle class are perceived to be well preferred than those from lower class. Primary school educators were found that when educators were well-informed regarding learners' socio-economic status, they were also performing in kindness of those from better social positions [7]. Sprinthall and Sprinthal concluded that in cases where learners belong to lower social position than educator, the conclusion can be educator favoritism for learners that originate from an analogous background [12].

Gender is a congenital and certainly reasonable characteristic. Occasionally educators can be predisposed by gender. Female educators can have an inclination to preferring male learners, and male educators may preferring female learners. The contrary, that is preferring the learners of the similar gender, is also a mutual inclination. Numerous emotional or social reasons can inspire by educator's deeds. Instinctively or not, we could not repudiate the circumstance that educators typically incline to provide exceptional kindness to boys. What is inferior, boys in some way appear to poster that jump to undertake a monitoring attitude, interjecting girls and challenging more from educators [14].

Preliminary from pre-school, educators have perceived to assess capacity of learners depends upon exclusively on their physical attributes. They shape their former imprint on learners' physical presence and preferring those who are well-looking. A relationship has been stated in literature between supposed attraction of learner by educator and supposed academic astuteness [12]. Examining educators and school learners whether physically attractive and educator anticipations are reproduced in learner marks. Felson concluded that physically good-looking learners were supposed to be more brilliant and therefore allocated more marks [3]. Furthermore, he stated that physically unpleasant learners were responsively distinguished beside [12]. Likewise, in another study showed that female primary school, high school and college learners, physically good-looking learners were found to get good marks [8].

Educators can occasionally be relative, guardian, or family friend of learner. Favoritism is very plausible in that cases. Mechtenberg concluded that "I study a one round cheap conversation game with two diverse form of senders (biased and fair educators), two forms of receivers ("special" and "normal learners") and ambiguity regarding the sender form on the side of receiver. I determine that cluster of learners who, in anticipation, get either too little or too much reinforcement will take fewer top successes and a lesser normal accomplishment than the cluster of learners who get a good correct reaction, even if previous capacity spreading is the equal for both clusters of learners". I undertake that biased behavior has its origins in the favorites of those who display this behavior. I think that "special learners" are also preferences or sufferers of perception. Their capacities can distortion with being educator's preferred [4].

A number of researchers have showed teachers favoritism in their studies [2] [6] [10]. These studies discover favoritism occurs in educational organizations in this contemporary world. Instead of these studies the investigators assured that there is a requirement to explore learners' perceptions about favoritism in teacher training institutions. No work has been done to examine learners' perceptions regarding favoritism in teacher training institutions of Pakistan. To examine learners' opinions regarding favoritism particularly in educator training institution is the requirement of the time and planned study is to discourse this requirement.

\section{Statement of the Problem}

Favoritism is a burning issue which occurs in all organizations particularly in educational organizations of this contemporary world. The present study intended to explore the opinions of pupil teachers about educators' favoritism at Institute 
of Education and Research, University of the Punjab, Lahore.

\section{Objectives of the Study}

- To explore the opinions of pupil teachers about educators' favoritism.

- To identify the dominant factor/s of educators' favoritism.

\section{Research Questions}

- What are the opinions of pupil teachers about educators' favoritism?

- Which is the dominant factor/s of educators' favoritism?

- What is the significant difference between the opinions of female and male pupil teachers about favoritism?

- What is the significant difference between the opinions of pupil teachers about favoritism on the basis of program?

\section{Research Methodology}

Quantitative approach was adopted whereas descriptive research design was used with the help of self-report survey. The population was contained of all the pupil teachers enrolled in Master Degree Program both morning and self-supporting at Institute of Education and Research (IER), University of the Punjab, Lahore. 225 (15 from morning while 10 from self-supporting) pupil teachers of each department of IER were selected by using nonproportional stratified random sampling method. Adapted questionnaire was used to collect data which was developed by Dr. Ismail Aydogan [2] in Turkey. Scale was contained of 28 statements under four subscales (nature of preference, violation of rules, students' assessment and terms of communication). Each item of each sub-scale was rated on five point likert type scale ranging from strongly disagree " 1 " to strongly agree " 5 ". The scale reliability value was good $(\alpha=.88)$. Frequencies, Percentage, Mean, and Standard Deviation were applied to analyze the descriptive data however, $\mathrm{t}$-test was applied to find out the difference between male and female, morning and self-supported pupil teachers through SPSS.

\section{Results of the Study}

Table depicts that the mean score of students' perception about two sub-scales of favoritism "nature of preference" and "students' assessment" was greater $(\mathrm{M}=31.44, \mathrm{SD}=2.67 ; \mathrm{M}=31.29, \mathrm{SD}=2.83)$ than the subscales "violation of rules" and "terms of communication" (M=30.75, $\mathrm{SD}=1.90 ; \mathrm{M}=29.91$, $\mathrm{SD}=2.54)$. Overall the perception of students showed the existence of favoritism at the Institute of Education and Research $(\mathrm{M}=123.39, \mathrm{SD}=7.41)$. It may be inferred that "nature of preference" is the dominant factor of teachers' favoritism followed by the students' assessment and violation of rules while the terms of communication is also the factor of teachers' communication contributing at lowest level.

Table 1. Summary statistics of perception of students about teachers' favoritism

\begin{tabular}{lllll}
\hline Variables & Min & Max & Mean & $S D$ \\
\hline $\begin{array}{l}\text { Nature of } \\
\text { Preference }\end{array}$ & 26.00 & 35.00 & 31.44 & 2.67 \\
$\begin{array}{l}\text { Violation of } \\
\text { Rules }\end{array}$ & 28.00 & 34.00 & 30.75 & 1.90 \\
$\begin{array}{l}\text { Students' } \\
\text { Assessment }\end{array}$ & 28.00 & 35.00 & 31.29 & 2.83 \\
$\begin{array}{l}\text { Terms of } \\
\text { Communication }\end{array}$ & 27.00 & 35.00 & 29.91 & 2.54 \\
Total & 110.00 & 133.00 & 123.39 & 7.41 \\
\hline
\end{tabular}

Table 2. Comparison of male and female students' perception about favoritism subscales

\begin{tabular}{|c|c|c|c|c|c|c|}
\hline & \multicolumn{2}{|c|}{ Male (56) } & \multicolumn{2}{|c|}{ Female (169) } & \multirow[t]{2}{*}{$t$} & \multirow[t]{2}{*}{$p$} \\
\hline & $M$ & $S D$ & $M$ & $S D$ & & \\
\hline 1 & 30.80 & 2.74 & 31.66 & 2.63 & -2.09 & .04 \\
\hline 2 & 30.27 & 1.82 & 30.91 & 1.91 & -2.21 & .03 \\
\hline 3 & 31.21 & 2.85 & 31.31 & 2.83 & $\overline{-}-23$ & .82 \\
\hline 4 & $\begin{array}{l}28.07 \\
122.36\end{array}$ & $\begin{array}{c}2.67 \\
7.91\end{array}$ & $\begin{array}{l}29.85 \\
123.73\end{array}$ & $\begin{array}{c}2.50 \\
7.31\end{array}$ & $\begin{array}{l}.56 \\
-1.19\end{array}$ & $\begin{array}{c}.58 \\
.23\end{array}$ \\
\hline
\end{tabular}

Table depicts that the mean score for female students was greater in all sub-scales of favoritism $(\mathrm{M}=31.66, \mathrm{SD}=2.63 ; \mathrm{M}=30.91, \mathrm{SD}=1.91 ; \mathrm{M}=31.31$, $\mathrm{SD}=2.83 ; \mathrm{M}=29.85, \mathrm{SD}=2.50)$ than the male students $(\mathrm{M}=30.80, \mathrm{SD}=2.74 ; \mathrm{M}=30.27, \mathrm{SD}=1.82 ; \mathrm{M}=31.21$, $\mathrm{SD}=2.85 ; \mathrm{M}=28.07, \mathrm{SD}=2.67)$. Overall the mean score for female students' perception about favoritism was greater $(\mathrm{M}=123.73, \mathrm{SD}=7.31)$ than the male students $(\mathrm{M}=122.36, \mathrm{SD}=7.91)$. The findings of t-test showed that there was significant difference between the perception of male and female students in two subscales 'nature of preference' and 'violation of rules' [t $(223)=-2.09, \mathrm{p}=.04 ; \mathrm{t}(223)=-2.21, \mathrm{p}=$ $.03]$. On the other hand, there was statistically insignificant difference between the opinions of female and male pupil teachers in rest of the two subscales [ $\mathrm{t}(223)=-.23, \mathrm{p}=.82 ; \mathrm{t}(223)=.56, \mathrm{p}=.58]$. Overall there was insignificant difference between the female and male pupil teachers' opinions about 
favoritism t $(223)=-1.19, \mathrm{p}=.23$. female and male pupil teachers have almost same level of perception about the favoritism.

Table 3. Comparison of students' perception about favoritism on the basis of program

\begin{tabular}{|c|c|c|c|c|c|c|}
\hline & \multicolumn{2}{|l|}{$\begin{array}{l}\text { Morning } \\
(136)\end{array}$} & \multicolumn{2}{|c|}{ Self-Support (89) } & \multirow[t]{2}{*}{$t$} & \multirow[t]{2}{*}{$p$} \\
\hline & $M$ & $S D$ & $M$ & $S D$ & & \\
\hline 1 & 31.24 & 2.71 & 31.76 & 2.59 & -1.45 & .15 \\
\hline 2 & 30.66 & 2.00 & 30.89 & 1.74 & -.87 & .39 \\
\hline 3 & 30.93 & 2.75 & 31.84 & 2.87 & -2.40 & .02 \\
\hline \multirow[t]{2}{*}{4} & 29.88 & 2.53 & 29.94 & 2.56 & -.18 & .86 \\
\hline & 122.71 & 7.62 & 124.44 & 7.23 & -1.70 & .09 \\
\hline
\end{tabular}

Table showed that the mean score for self-support program students was greater in all subscales of favoritism $(\mathrm{M}=31.76, \mathrm{SD}=2.59 ; \mathrm{M}=30.89, \mathrm{SD}=1.74$; $\mathrm{M}=31.84, \mathrm{SD}=2.87 ; \mathrm{M}=29.94, \mathrm{SD}=2.56)$ than the morning program students $(\mathrm{M}=31.24, \mathrm{SD}=2.71$; $\mathrm{M}=30.66, \mathrm{SD}=2.00 ; \mathrm{M}=30.93, \mathrm{SD}=2.75 ; \mathrm{M}=29.88$, $\mathrm{SD}=2.53)$. Overall the mean score for self-support program students' perception about favoritism was greater $(\mathrm{M}=124.44, \mathrm{SD}=7.23)$ than the morning program students $(\mathrm{M}=122.71, \mathrm{SD}=7.62)$. The results of t-test illustrate that there was significant difference between the perception of morning and self-support program students in one subscale students' assessment $\mathrm{t}(223)=-2.40, \mathrm{p}=.02$. Nevertheless, there was statistically insignificant difference between the opinions of morning and self-support program students in all other sub-scales $[\mathrm{t}(223)=-$ $1.45, \mathrm{p}=.15 ; \mathrm{t}(223)=-.87, \mathrm{p}=.39 ; \mathrm{t}(223)=-.18, \mathrm{p}$ $=.86]$. Overall there was insignificant difference between the perception of morning and self-support program students about favoritism t $(223)=-1.70$, $\mathrm{p}=.09$. Morning and self-support program students have almost the same level of perception about the favoritism.

\section{Conclusion}

Majority of the pupil teachers agreed that favoritism exists in the Institute. Nature of preference is the dominant factor of teachers' favoritism. Findings concluded that majority of the educators give preference to female pupil teachers instead of male pupil teachers. Educators give preference to those pupil teachers who are quite close, handsome and beautiful. In case of female pupil teachers, educators tolerate violation in classroom rules. Educators give additional marks in examination and assignments to female good-looking/attractive learners. Moreover, educators also give preference to those learners who hold analogous ideologies with educator. Results concluded that there was insignificant difference between the opinions of female and male pupil teachers about favouritism in the Institute of Education and Research (IER). Moreover, there was insignificant difference in the opinions of pupil teachers about favouritism in IER on the basis of program (Morning \& Selfsupporting).

\section{Discussion}

This study aims to determine the perception of pupil teachers about educators' favouritism and also identifies the dominant factor of educators' favouritism in teacher training institute of Pakistan. The results of this study portrays that the perceptions of pupil teachers regarding the educators' favouritism are at "intensively agree" level and educators prefer socially well-placed, beautifulthandsome, relative and ideologically closed students/pupil teachers. This finding is in line with the results of the researchers carried out by Aydogan [2], Okcu and Ucar [6], Shneikat, Abubakar and Ilkan, [10]. Findings of this study further revealed that there was no difference in the perception of pupil teachers about favoritism with respect to gender. This finding is supported with the results of the researches conducted by Aydagon [2], Shneikat, Abubakar and Ilkan, [10]. It is also observed that there was insignificant difference between the opinions of morning and self-supporting program pupil teachers about favouritism in IER.

\section{Recommendations and Future Study Directions}

This study has several recommendations for future study.

- Forthcoming studies would be conducted on huge sample size of other countries with dissimilar educational settings.

- In-service trainings and seminars can be organized for the students to raise awareness about the favoritism.

- For accountability determination, the organizations need to make casual interactions with the learners.

- Every student would be treated fairly. They would not be exhilarated on the basis of their presences, gender and social status.

- Empathy should be developed with students.

- Secure atmosphere should be provided in which students can talk about any situation which they consider unfair.

- This research was carried out with the 
quantitative data collection tools; it may also be carried out with qualitative data collection tools and at different stages of education.

\section{References}

[1] Arasli, H., \& Tumer, M. (2008). Nepotism, favoritism and cronyism: A study of their effects on job stress and job satisfaction in the banking industry of north Cyprus. Social Behavior and Personality, 36(9), 1237-1250.

[2] Aydogan, I. (2008). Favoritism in the classroom: A study on Turkish schools. Journal of Instructional Psychology, 35(2), 159-167.

[3] Felson, R. B. (1980). Physical attractiveness, grades and teachers' attributions of ability. Representative Research in Social Psychology.

[4] Mechtenberg, L. (2006). Cheap talk in the classroom. Retrieved from http://sfb649.wiwi. huberlin. de/papers/pdf/SFB649DP2006-019.pdf.

[5] Nadler, J. \& M. Schulman. (2006). Favoritism, cronyism, and nepotism.International Journal of Behavioral Development, 37(3), 202-210.

[6] Okçu, V., \& Uçar, A. (2016). Effect of school principals' favouritism behaviors and attitudes on teachers' organizational commitment, based on the perceptions of primary and secondary school teachers. Journal of Human Sciences, 13(3), 59015914.

[7] Ozturk, B., Sahin, F. T., \& Koc, G. (2002). Student behaviors that affect teacher expectations in primary schools. Educational Management in Theory and Practice, 8(31), 390-413.

[8] Ritts, V., Patterson, M. L., \& Tubbs, M. E. (1992). Expectations, impressions, and judgments of physically attractive students: A review. Review of educational research, 62(4), 413-426.

[9] Roy, M., \& Roy, F. (2004). An empirical analysis of favoritism during business training. Industrial and Commercial Training, 36(6), 238-242.

[10] Shneikat, B., Abubakar, M. A., \& Ilkan, M. (2016). Impact of Favoritism/Nepotism on Emotional Exhaustion and Education Sabotage: The Moderating Role of Gender. Harvard Academic Forum, 9(1), 3849.
[11] Sprinthall, NA; Sprinthall, R.C. (1990). Educational psychology. New York: McGraw-Hill.

[12] Tauber, R. T. (1997). Self-fulfilling prophecy: A practical guide to its use in education. Greenwood Publishing Group.

[13] The Coalition for Accountability and Integrity (30 and 31 December 2004). Opinion poll on corruption in the Palestinian society WASTA (Favoritism and Nepotism), Retreived22 december, 2007, from http:/ /www.transparency. org/content/download/1587/8162/file/palestine_poll. pdf.

[14] Vicente, H. D. (1999). Gender relations in the classroom. New Routes in ELT, 16-17. 